\title{
THE ESTIMATION OF CATECHOLAMINES IN URINE BY A CHEMICAL METHOD
}

\author{
BY \\ H. WEIL-MALHERBE AND A. D. BONE \\ From the Research Laboratory, Runwell Hospital, Wickford, Essex
}

(ReCeived for publication may 9, 1956)

The estimation of urinary catecholamines has assumed clinical significance mainly because of its value in the diagnosis of phaeochromocytoma (Engel and Euler, 1950 ; Euler, 1951). Since biological methods have obvious limitations for routine work, various chemical methods have been developed (Lund, 1950; Pekkarinen and Pitkänen, 1955 ; Euler and Floding, 1955a, b). They are based on the same principle: catechol compounds are isolated by adsorption on aluminium oxide and adrenaline and noradrenaline are subsequently oxidized to fluorescent trihydroxyindoles.

In addition to adrenaline and noradrenaline a third catecholamine occurs in urine, namely 3-hydroxytyramine (Holtz, Credner, and Koepp, 1942 ; Euler and Hellner, 1951 ; Euler, Hamberg, and Hellner, 1951). Few quantitative data about its rate of excretion are available at present (Euler et al., 1951; Hoobler, Agrest, and Warzynski, 1954; Abelin and Goldstein, 1955); they were obtained by means of chromatographic procedures which can, at best, be regarded as semi-quantitative.

In the method here proposed the three catecholamines are quantitatively estimated by a combination of the fluorimetric methods of WeilMalherbe and Bone (1952) and Euler and Floding (1955a). The former estimates the sum of the three catecholamines; adrenaline and noradrenaline are estimated separately by the second method; hydroxytyramine is obtained by difference.

Euler, Euler, and Floding (1955) have shown the occurrence of relatively large amounts of $3: 4$ dihydroxyphenylacetic acid (catecholacetic acid) in urine. This substance and any other acidic catechol may be separated from catechol bases by ion exchange. After passage through an anion exchange resin the catechol bases are found in the filtrate. On a cation exchange resin they are themselves retained. We have chosen cation exchange as the more specific procedure in which neutral interfering substances whose presence in urine has been claimed, such as catechol (Fiker, 1953) or 3:4-dihydroxybenzaldehyde (Kawamoto, 1954), would also be eliminated. The resin treatment is preceded by the passage of the urine sample through a column of aluminium oxide, essentially as described for plasma (Weil-Malherbe and Bone, 1952).

The higher purification resulting from the cation exchange procedure is of advantage even if it is desired to estimate only adrenaline and noradrenaline. Better results were obtained when the methods of Lund (1950) or of Euler and Floding (1955a) were applied to urine extracts purified in this way than when they were used in their original $\stackrel{\perp}{\perp}$ form, i.e., after alumina adsorption only. The $\overrightarrow{\overrightarrow{0}}$ advantages were that the blank was lower, indi- 3 cating the removal of non-specific fluorescence, and that recoveries were better, indicating perhaps the removal of quenching impurities. Eluates from alumina columns usually contain a reddish pigment which forms a flocculent precipitate in alkaline solution. This material is eliminated in the resin treatment.

\section{Method}

Reagents.-The following reagents are required : $1 \%(\mathrm{w} / \mathrm{v})$ disodium ethylenediamine tetra-acetate (E.D.T.A.).

$2 \%(w / v)$ ascorbic acid, freshly prepared.

Aluminium oxide, acid-washed (Weil-Malherbe and N Bone, 1952).

$0.2 \mathrm{M}$-sodium acetate, purified with cation exchange resin (Weil-Malherbe and Bone, 1952) and adjusted to pH 8.4 with $0.5 \mathrm{~N}-\mathrm{Na}_{2} \mathrm{CO}_{3}$.

$0.2 \mathrm{~N}$-acetic acid.

"Zeokarb" 225, water regain 1.8, 40-70 mesh, $\mathrm{H}^{+-}$ form (Permutit Co.).

$0.2 \mathrm{M}$-barium chloride.

$1 \mathrm{M}$-acetate buffers, $p \mathrm{H} 3.5$ and 6.0 .

$0.25 \%(\mathrm{w} / \mathrm{v})$ potassium ferricyanide.

$0.5 \%(\mathrm{w} / \mathrm{v})$ zinc sulphate.

Alkaline ascorbate: $1 \mathrm{ml} .2 \%(\mathrm{w} / \mathrm{v})$ ascorbic acid +8 $9 \mathrm{ml} .5 \mathrm{~N}-\mathrm{NaOH}$ mixed immediately before use. 
2 M-ethylenediamine dihydrochloride, purified according to Weil-Malherbe and Bone (1954a).

Ethylenediamine, redistilled.

iso Butonal.

$\mathrm{NaOH}: 1 \mathrm{~N}$ - and $5 \mathrm{~N}$-solutions. $\mathrm{H}_{2} \mathrm{SO}_{4}, 10 \mathrm{~N}$ solution.

Standard Solutions.-Stock solutions of amines (Ladrenaline bitartrate, Burroughs-Wellcome \& Co.; L-noradrenaline bitartrate, Bayer ; DL-hydroxytyramine hydrochloride, California Foundation for Biochemical Research), containing $100 \mu \mathrm{g}$. of free base per ml., were prepared in $0.01 \mathrm{~N}-\mathrm{HCl}$ and kept at about $0^{\circ} \mathrm{C}$. for up to six weeks. Dilute solutions containing $0.1 \mathrm{~kg} . / \mathrm{ml}$. were prepared in $0.01 \mathrm{~N}-\mathrm{HCl}$ and kept at $0^{\circ} \mathrm{C}$. for three to four days.

Other Chemicals.-L-3:4-dihydroxyphenylalanine, Roche Products.

3:4-Dihydroxyphenylacetic acid prepared from $3: 4-$ dimethoxyphenylacetic acid by refluxing with hydrobromic acid (Abbott and Smith, 1949).

Water redistilled in glass was used throughout.

(1) Hydrolysis. - The acidified sample of urine $(p \mathrm{H} 1.0-1.5)$ is refluxed for $20 \mathrm{~min}$. and cooled.

(2) Adsorption on Column of Aluminium Oxide.After the addition of $5 \mathrm{ml}$. E.D.T.A.-solution and $1 \mathrm{ml}$. ascorbic acid solution to $50 \mathrm{ml}$. of hydrolysed urine the $p \mathrm{H}$ is adjusted to 8.4 with $1 \mathrm{~N}-\mathrm{NaOH}$ (approx. $5 \mathrm{ml}$.). Rapid stirring and continuous $p \mathrm{H}$ control with the aid of a glass electrode are essential. Usually the mixture remains clear, but occasionally a slight precipitate forms at this stage. Whether a visible precipitate appears or not the solution is clarified by centrifuging for about $5 \mathrm{~min}$. at 2,000 r.p.m. so as to remove suspended strands of mucine, etc., which might impede the flow through the column.

Thistle funnels of the kind described by WeilMalherbe and Bone (1952) are used for chromatography on aluminimum oxide. Filtration is carried out under a pressure of about 30 to $40 \mathrm{~mm}$. $\mathrm{Hg}$, supplied from a cylinder of nitrogen or compressed air. Independent adjustment of pressure to the desired rate of filtration (about $1 \mathrm{ml}$./min.) in each individual unit is achieved by means of a pressure manifold with eight places (Bone, 1953). Since the thistle funnels in use in this laboratory have bulbs with a capacity of about $40 \mathrm{ml}$. it has been our practice to divide the sample of urine between two columns and pool the eluate, but the total may be passed over one column if preferred.

The columns are prepared by placing $0.7 \mathrm{~g}$. of dry aluminium oxide in the bulb of the thistle funnel held horizontally and washing it down into the stem with $5 \mathrm{ml}$. sodium acetate solution. The urine sample is added next. The column is washed through with $5 \mathrm{ml}$. acetate solution, followed by $5 \mathrm{ml}$. water. The urine filtrate and the washings are discarded. Elution is carried out by passing $5 \mathrm{ml} .0 .2 \mathrm{~N}$-acetic acid, followed by $5 \mathrm{ml}$. water, over the column.

(3) Adsorption on Column of "Zeokarb" 225.-The thistle funnels used for this stage are slightly larger (stem with $6 \mathrm{~mm}$. bore) than those for the alumina columns. They are fitted below the constriction with plastic taps and tapered jets (Townson and Mercer Ltd.) which allow a fine regulation of flow. Before use the resin is carried through several cycles by alternately treating it with dilute $\mathrm{NaOH}$ and dilute $\mathrm{HCl}$; it is washed well and stored in water. The required quantity is sucked as dry as possible on a sinteredglass funnel and weighed moist. Two grammes are rinsed into the stem of the funnel with water. Entrapped air is displaced by an upward flow of water.

The eluate from the alumina column is now added. Next the column is washed with $150 \mathrm{ml}$. $0.2 \mathrm{~N}$-acetic acid and eluted with $50 \mathrm{ml}$. $\mathrm{BaCl}_{2}$-solution. The rate of flow should not exceed $0.67 \mathrm{ml} . / \mathrm{min}$. The procedure lasts four or five hours, but little supervision is needed. The eluate is treated with a slight excess of $10 \mathrm{~N}-\mathrm{H}_{2} \mathrm{SO}_{4}(2 \mathrm{ml}$.) and the precipitate of barium sulphate centrifuged off. The supernatant is brought to $p \mathrm{H} 4.0$ with $1 \mathrm{~N}-\mathrm{NaOH}$ (about $20 \mathrm{ml}$.), precise adjustment being controlled with the glass electrode.

(4) Condensation with Ethylenediamine (WeilMalherbe and Bone, 1952).-A 2 or $3 \mathrm{ml}$. sample of the eluate is made up to $10 \mathrm{ml}$. in a glass-stoppered test tube $(20 \times 1.5 \mathrm{~cm}$. $)$ and mixed with $0.5 \mathrm{ml}$. ethylenediamine dihydrochloride solution and $0.7 \mathrm{ml}$. ethylenediamine. In addition, three standards containing $0.2 \mu \mathrm{g}$. of adrenaline, noradrenaline, or hydroxytyramine, respectively, and a reagent blank are similarly treated. The tubes are heated for 20 min. at $50^{\circ}$. The solutions are cooled, saturated with solid $\mathrm{NaCl}$ (ca. 3.5 g.) and extracted with $6 \mathrm{ml}$. isobutanol by mechanical shaking for $4 \mathrm{~min}$. The solvent layer containing the fluorescent derivative is removed as completely as possible by aspiration with a rubber teat pipette.

(5) Oxidation with Ferricyanide (Euler and Floding, 1955a). - Three eluate samples, each of the same volume as the sample used for the ethylenediamine reaction, are required: one for the estimation of

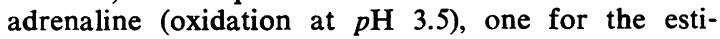
mation of the sum of adrenaline and noradrenaline (oxidation at $p \mathrm{H} \mathrm{6.0),} \mathrm{and} \mathrm{one} \mathrm{for} \mathrm{the} \mathrm{extract} \mathrm{blank}$ in which the fluorescence has been allowed to fade. In addition standards of adrenaline and noradrenaline $(0.2 \mu \mathrm{g}$.$) and a "faded-adrenaline blank" are set up ;$ the latter contains $0.2 \mu \mathrm{g}$. adrenaline and buffer of

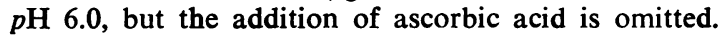
Buffer, zinc sulphate, and ferricyanide solutions, in that order, are added according to the schedule shown in Table I. The solutions are left for three min. before being mixed with alkaline ascorbate or $\mathrm{NaOH}$. Volumes are made up to $10 \mathrm{ml}$.

(6) Fluorimetry. - The apparatus previously described (Weil-Malherbe and Bone, 1953) is used with some modifications. The measuring unit now consists of a photomultiplier (R.C.A. 981 P.M. tube, purchased from Army surplus stocks) connected to a galvanometer (" scalamp" No. 7903/S. W. G. Pye \& 
TABLE I

SET-UP FOR FERRICYANIDE OXIDATION (METHOD OF EULER AND FLODING, 1955a)

\begin{tabular}{|c|c|c|c|c|c|c|c|c|}
\hline$\dot{\mathbf{z}}$ & 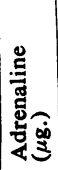 & Z & 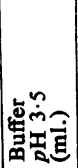 & 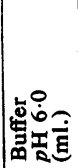 & 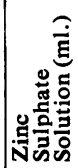 & & 吾 & z \\
\hline $\begin{array}{l}\text { Extract } \\
(2 \text { or } 3 \\
\text { ml.) }\end{array}$ & $=$ & $\bar{z}$ & $\begin{array}{l}1.0 \\
-\end{array}$ & $\begin{array}{l}\overline{1.0} \\
1.0\end{array}$ & $\begin{array}{l}0.1 \\
0.1 \\
0.1\end{array}$ & $\begin{array}{l}0 \cdot 1 \\
0 \cdot 1 \\
0 \cdot 1\end{array}$ & $\begin{array}{l}1.0 \\
1.0 \\
-\end{array}$ & $\overline{1.0}$ \\
\hline $\begin{array}{l}\text { Stan- } \\
\text { dards }\end{array}\left\{\begin{array}{l}1 \\
2 \\
3\end{array}\right.$ & $\frac{0.2}{0.2}$ & $\overline{0 \cdot 2}$ & $\frac{1.0}{-}$ & $\begin{array}{l}\overrightarrow{1.0} \\
1.0\end{array}$ & $\begin{array}{l}0.1 \\
0 \cdot 1 \\
0 \cdot 1\end{array}$ & $\begin{array}{l}0 \cdot 1 \\
0 \cdot 1 \\
0 \cdot 1\end{array}$ & $\begin{array}{l}1.0 \\
1.0 \\
-\end{array}$ & $\frac{\bar{T}}{1.0}$ \\
\hline
\end{tabular}

Co., with modified sensitivity settings of $1.0,0.2$, and 0.05). It is powered by stabilized D.C. of 1,000 volts at $8 \mathrm{~mA}$. The circuit includes a "backing-off" circuit from a $1 \frac{1}{2} \mathrm{v}$. battery which opposes the photomultiplier current.

The silica cells with polished bottom are $40 \mathrm{~mm}$. high, $23 \mathrm{~mm}$. wide, and $10 \mathrm{~mm}$. deep. They are filled to a level about $15 \mathrm{~mm}$. below the top, thus containing about $5.5 \mathrm{ml}$. The cell carrier is fitted with a metal screen having $20 \times 20 \mathrm{~mm}$. square openings opposite the photomultiplier window. The overlapping sides of this screen cover the fused joints of the cuvette and the meniscus of the liquid. The optical system is arranged so as to fill the entire bulk of the liquid with diffuse fluorescence. All fluorescence measurements are made through a yellow secondary filter (Chance OY4).

The appropriate reagent blanks are used to adjust the galvanometer needle to zero by operating the variable control of the backing-off circuit. Under our conditions the ethylenediamine reagent blank, read against pure isobutanol, gives a deflection corresponding to that of a $0.01-0.02 \mu \mathrm{g}$. adrenaline standard. If read against the dark current the deflection corresponds to $0.06 \mu \mathrm{g}$. adrenaline. The " faded adrenaline blank," and also pure water, read against the dark current, give a deflection corresponding to $0.025 \mu \mathrm{g}$. adrenaline. The "backing-off" of these blank readings does not impair the linearity, accuracy, and reproducibility of the adrenaline measurements down to amounts of about $0.003 \mu \mathrm{g}$.

(7) Calculation.-These are for ferricyanide oxidation and ethylenediamine condensation.

\section{Ferricyanide Oxidation}

Let $\mathrm{a}=$ reading of extract oxidized at $p \mathrm{H} 3.5$

$\mathrm{b}=$ reading of extract oxidized at $p \mathrm{H} 6.0$ (both corrected for extract blank)

$\mathrm{c}=$ reading of adrenaline standard $(0.2 \mu \mathrm{g}$.)

$\mathrm{d}=$ reading of noradrenaline standard $(0.2 \mu \mathrm{g}$.)

Then the amount of adrenaline (A) in the eluate sample

A $\frac{0.2 \mathrm{a}}{\mathrm{c}} \mu \mathrm{g}$. , and of noradrenaline $\mathrm{N}=\frac{0.2(\mathrm{~b}-\mathrm{a})}{\mathrm{d}} \mu \mathrm{g}$.

The small proportion of noradrenaline oxidized at pH 3.5 (4\% according to Euler and Floding, 1955a) is here neglected.

\section{Ethylenediamine Condensation}

Let $\mathrm{e}=$ reading of sample

$\mathrm{f}=$ reading of adrenaline standard $(0.2 \mu \mathrm{g}$.

$\mathrm{g}=$ reading of noradrenaline standard $(0.2 \mu \mathrm{g}$.

$\mathrm{h}=$ reading of hydroxytyramine standard $(0.2$

$\mu \mathrm{g}$ ), also $A$ and $N=\mu \mathrm{g}$. of adrenaline and noradrenaline, respectively, as determined by ferricyanide oxidation.

Then the amount of hydroxytyramine $=$

$$
\frac{0.2 \mathrm{e}-\mathrm{A} \times \mathrm{f}-\mathrm{N} \times \mathrm{g}}{\mathrm{h}} \mu \mathrm{g} \text {. }
$$

Results are expressed per litre or per 24 hours, taking into account the appropriate dilution corrections. If the resin eluate has been treated with $2.1 \mathrm{ml} .10$ $\mathrm{N}-\mathrm{H}_{2} \mathrm{SO}_{4}$ and $20 \mathrm{ml}$. $\mathrm{N}-\mathrm{NaOH}$, and if $2 \mathrm{ml}$. samples were used for the analyses, the amounts of catecholamines determined are those originally present in 1.39 ml. of urine.

\section{Comment on the Method}

(1) Hydrolysis.-Preliminary hydrolysis of the urine at $p \mathrm{H} 1-1.5$ for $20 \mathrm{~min}$. ensures the inclusion of the phenolic sulphate fraction of $\vec{\oplus}$ conjugated catecholamines in the estimate. O] Glucuronides are, however, not hydrolysed under these conditions; excretion of catecholamine glucuronides has been reported by Clark, Akawie, Pogrund, and Geissman (1950) and by Elmadjian, Lamson, and Neri (1955).

(2) Stability of Catecholamines in Urine.-As pointed out by Mann (1953), adrenaline and noradrenaline are more stable in urine than in aqueous solution, owing to the presence of phosphates and ascorbic acid in combination. Acidification further enhances the stability of urinary catecholamines. It is advisable, therefore, when collecting 24-hour urine to acidify each portion with 0.01 vol. concentrated $\mathrm{HCl}$ immediately after it has been voided. To afford additional protec-

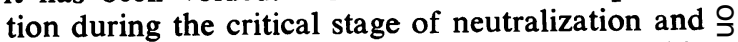
to replace losses due to heating $20 \mathrm{mg}$. ascorbic acid is added before neutralizing.

(3) Adsorption on Aluminium Oxide.-On rais- $N$ ing the $p \mathrm{H}$ of hydrolysed urine to 8.4 a gelatinous $N$ precipitate sometimes appears. Addition of phos- N phate buffer at this stage (Weil-Malherbe and $\omega$ Bone, 1954a) produces a more copious, granular precipitate; however, some specimens of phos- $\stackrel{\circ}{\simeq}$ phate were found to entail losses of catecholamines. The formation of a precipitate can be ${ }^{+}$ almost completely prevented by the addition of $\frac{T}{0}$ E.D.T.A. whose chelating properties may also $\overrightarrow{\mathbb{D}}$ have an antioxidant effect.

The appearance of a troublesome precipitate or $\stackrel{\mathbb{Q}}{\varrho}$ losses during the final stages of $p \mathbf{H}$ adjustment have induced some authors (Pekkarinen ando 
Pitkänen, 1955 ; Euler and Orwén, 1955) to abandon column adsorption in favour of batch adsorption, necessitating repeated washings and the handling of relatively large volumes of eluate. With the modifications described there is no longer any need to forgo the simplicity and elegance of the column procedure.

(4) Cation Exchange Chromatography.-Bergström and Hansson (1951) used " amberlite "IRC50, a carboxylic resin, to adsorb adrenaline from solutions buffered at $p \mathrm{H}$ 6.5. This method was found satisfactory for pure solutions of adrenaline, but results with urine were erratic owing to variable retention of adrenaline. More strongly acidic resins were therefore investigated and sulphonated polystyrene resins, such as "dowex" 50 or "zeokarb" 225 , proved satisfactory, provided they had a low degree of cross-linking $(4-5 \%)$. Barium chloride solution was chosen as eluant because of the greater eluting effect of the bivalent cation; to obtain a similar effect with either $\mathrm{NaCl}$ or $\mathrm{HCl}, 2-\mathrm{M}$-solutions had to be used. Moreover, by precipitation of barium sulphate and by removal of chloride ions with anion exchange resin solutions may be obtained which are low in salt concentration and therefore suitable for paper chromatography.

The addition of $1 \%$ benzyl alcohol, recommended by Moore and Stein (1951) for the elution of aromatic amino-acids, did not accelerate the elution of catecholamines.

The separation of catechol acetic acid from catechol bases by the resin column was followed by analysing urinary extracts with both the ethylenediamine condensation and the ferricyanide oxidation methods until the ratio of the figures became constant, and further by studying catechol acetic acid in pure solution and in mixture with catecholamines. It was found that 70 $80 \%$ of the acid was contained in the filtrate and the first $10 \mathrm{ml}$. of washings. The remainder seemed to be firmly adsorbed on the resin, presumably by a non-ionic mechanism. It could not be removed by large volumes of water. Of various solutions tested none was better than 0.2 $\mathrm{N}$-acetic acid for eluting acidic catechols without causing losses of basic catechols.

When a urine extract, purified by passage over a column of alumina, is run through a column of anion exchange resin ("dowex" $2, \mathrm{Cl}^{\prime}$-form), catecholamines are found in the effluent, but, although catechol acetic acid is retained, the filtrate gives a $50-100 \%$ higher fluorescence after ethylenediamine condensation than an eluate from the cation exchange resin. It is concluded that urine contains not only acidic but also neutral catechol compounds.

If any amino acids were present in the eluate from the alumina column they would be retained on the "zeokarb" column and would appear in the eluate. The only amino acid which has to be considered here is 3:4-dihydroxyphenylalanine (DOPA). Evidence for its absence will be presented later.

(5) Condensation with Ethylenediamine.-The conditions originally chosen were those which were found optimal for adrenaline (cf. Bone, 1953). With the extension of the method to other catecholamines it became desirable to repeat these experiments with noradrenaline and hydroxytyramine, particularly in view of a report of Erne and Canbäck (1955), who recommend, for noradrenaline, heating at $100^{\circ} \mathrm{C}$. for $5 \mathrm{~min}$. in the presence of ammonium molybdate solution as a catalyst. The development of fluorescence at $50^{\circ} \mathrm{C}$. and $100^{\circ} \mathrm{C}$., in the presence and absence of the molybdate catalyst, is shown in Fig. 1. The readings were corrected for reagent blank values which tended to increase with time and temperature, especially in the presence of molybdate. When the amines were heated at $50^{\circ} \mathrm{C}$., without molybdate, a steady end value was reached approximately within $20 \mathrm{~min}$. Raising the temperature to $100^{\circ} \mathrm{C}$. decreased the fluorescence intensity, especially in the case of adrenaline. The addition of molybdate had no catalytic effect at $50^{\circ} \mathrm{C}$.; its effect at $100^{\circ} \mathrm{C}$. varied with time and with each catecholamine. In the light of these results we saw no reason to modify our original technique.

It has been noted (Aronow and Howard, 1955) that the fluorescent derivative of noradrenaline is sensitive to light. We did not find this troublesome provided (1) the exposure to ultra-violet light is not unduly prolonged, (2) the intensity of ultraviolet irradiation is not excessive. For this reason in particular the sample is irradiated by a diffuse beam of ultra-violet light rather than by a sharply focused pencil of light. No deterioration of fluorescence was noted in diffuse daylight within 24 hours.

(6) Ferricyanide Oxidation.-According to Euler and Floding (1955a) the isomerization of the $2: 3$ dihydro-5:6-dioxoindoles (e.g., adrenochrome) to fluorescent 5:6-dihydroxyindoles is only possible if there is a hydroxyl group in position 3 of the indole ring. We have found, however, that oxidation of DOPA (whether by ferricyanide or by manganese dioxide) leads to the formation of a fluorescent product, presumably 5,6-dihydroxy- 


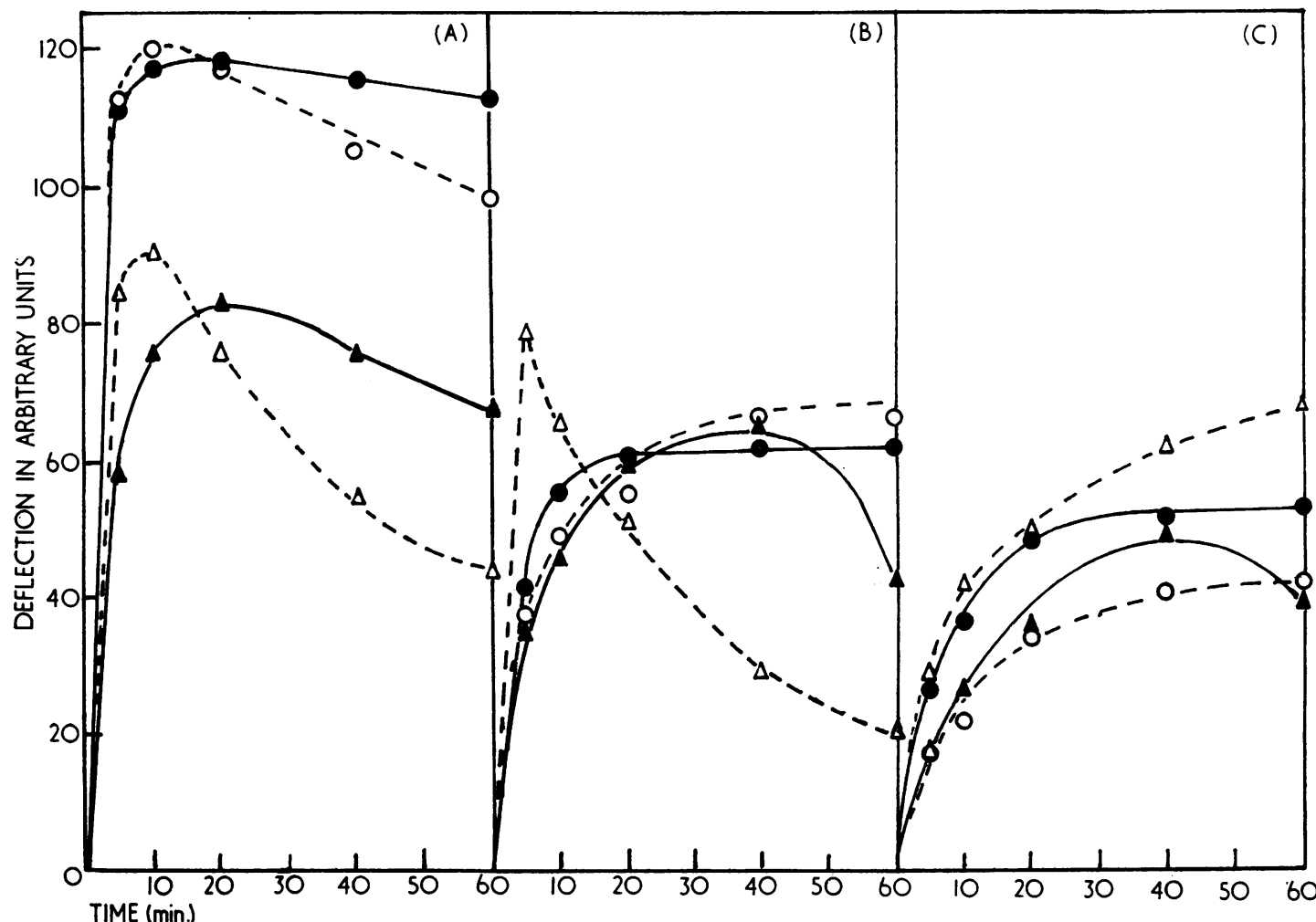

FIg. 1.-Fluorescence intensities of ethylenediamine condensation products. (a) With $0.1 \mu \mathrm{g}$. adrenaline; (b) with $0.2 \mu \mathrm{g}$. noradrenaline; (c) with $0.2 \mu \mathrm{g}$. hydroxytyramine. - After heating at $50^{\circ}$, without molybdate. $\bigcirc---\bigcirc$ After heating at $50^{\circ}$, in the presence of $0.03 \mathrm{ml} .10 \%(\mathrm{w} / \mathrm{v})$ ammonium molybdate in $5 \mathrm{~N}-\mathrm{HNO}_{3}$. $\Delta-\Delta$ After heating at $100^{\circ}$, without molybdate. $\triangle--\triangle$ After heating at $100^{\circ}$, with molybdate.

indole. It may be recalled in this connexion that the condensation product of ethylenediamine with DOPA is only slightly soluble in isobutanol, about $95 \%$ of the fluorescence remaining in the aqueous phase (Weil-Malherbe and Bone, 1952). It is possible, therefore, by a combination of the two fluorimetric methods, to differentiate between DOPA, hydroxytyramine, adrenaline, and noradrenaline.

In the method of Euler and Floding (1955a) the oxidation at $p \mathrm{H} 6$ is terminated after $2 \mathrm{~min}$. and the addition of the zinc sulphate catalyst is omitted. In our hands the results were better when the conditions were the same as for the oxidation at $p \mathrm{H} 3.5$, i.e., oxidation for $3 \mathrm{~min}$. in the presence of zinc sulphate. This is the only modification which we have introduced.

(7) Fluorimetry and Calculation. - Paperchromatographic examination of purified extracts of urine sometimes revealed components with blue fluorescence after spraying with ethylenediamine, but none with green or yellow fluorescence except in the positions occupied by catecholamines. The fluorimetric readings were therefore taken with the yellow filter.

A formula was developed for the estimation of the three catecholamines from differential fluorimetry of the ethylenediamine condensation products with green and yellow filters and from the fluorimetric estimation of the sum of adrenaline and noradrenaline as given by ferricyanide oxidation at $p \mathrm{H} 6$. Since the calculations were rather involved and the method offered no particular advantage, it was abandoned.

\section{Specificity}

Qualitative Paper Chromatography.-Purified urinary extracts were studied by one-dimensional paper chromatography on Whatman paper No. 1 (pretreated as described, Weil-Malherbe and Bone, 1954a), with two solvent systems: (1) nbutanol-acetic acid-water, 4:1:5 (descending technique ; approximate $\mathbf{R}_{\mathbf{F}}$-values ; noradrenaline 0.28 , adrenaline 0.31 , hydroxytyramine 0.38 ), (2) phenol-water, $3: 1(\mathrm{w} / \mathrm{v})$, over $5 \mathrm{~N}-\mathrm{HCl}$ (ascend- 
ing technique; approximate $R_{F}$-values: noradrenaline 0.30 , hydroxytyramine 0.48 , adrenaline 0.52). After precipitation and centrifugation of barium sulphate the eluate was diluted with 3 volumes of water (to avoid losses by adsorption) and the $p H$ was adjusted to 4.0 by the addition of "dowex" 2 ( $\mathrm{OH}^{-}$form). The resin was quickly filtered off by suction and thoroughly washed. The solution was concentrated in vacuo to $<0.5 \mathrm{ml}$. and the residue taken up in $5 \mathrm{ml}$. acid acetone $(0.5 \mathrm{ml}$. concentrated $\mathrm{HCl} / 100 \mathrm{ml}$.). Insoluble matter was discarded and the clear extract was again evaporated almost to dryness; solution in $5 \mathrm{ml}$. acid acetone and evaporation of the supernatant was repeated once more. The final residue was taken up in a small volume of acid acetone and transferred to paper in a line about $4 \mathrm{~cm}$. long. The chromatograms were run at room temperature for 16 hours. Butanol chromatograms were air-dried and were then frequently photographed in ultra-violet light by the technique of Markham and Smith (1951). Phenol chromatograms were washed in benzene and peroxide-free ether.

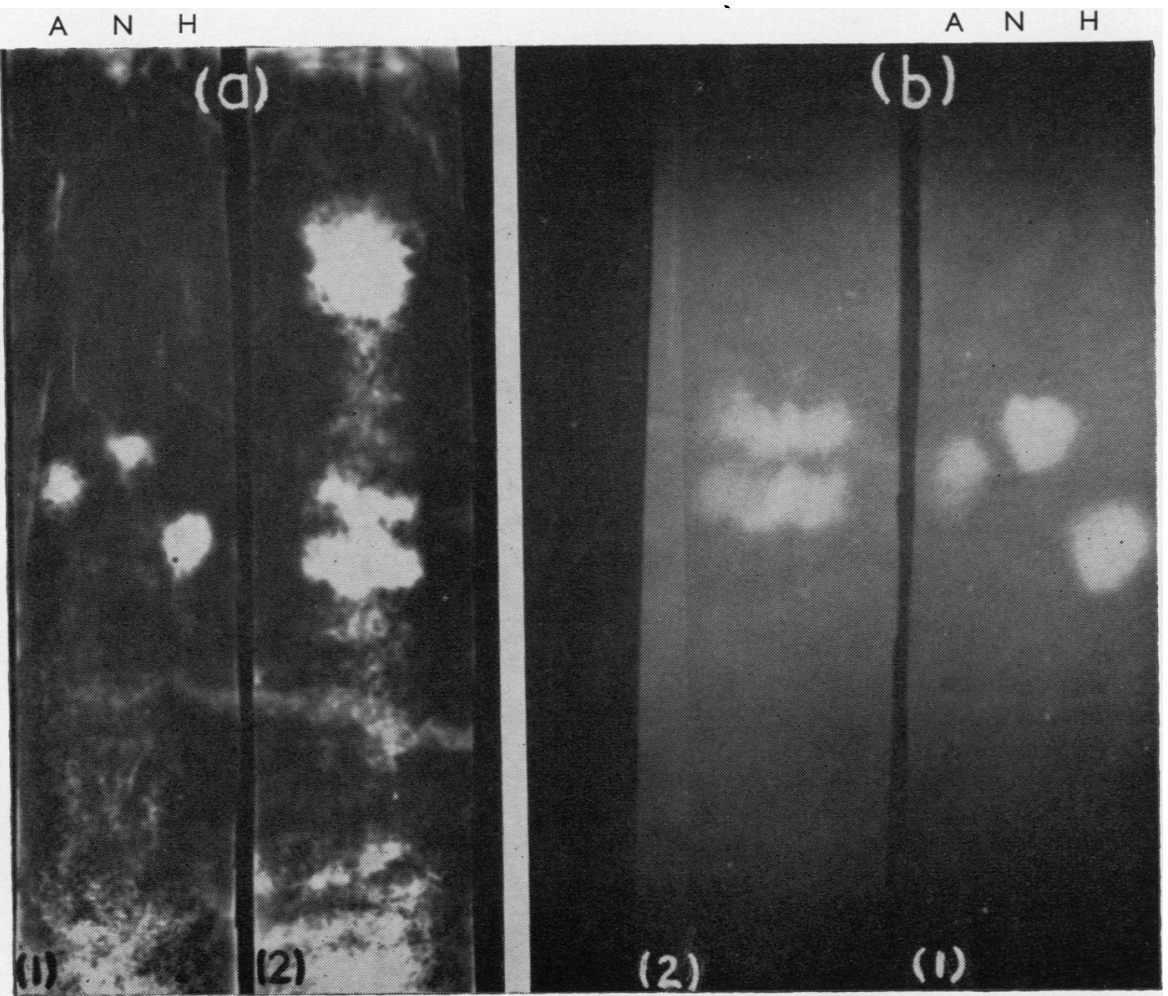

FIG. 2.-Chromatography of urinary extract (butanol-aceitc acid solvent). (a) Contact print in ultra-violet light: (1) guide strip with adrenaline $(A)$, noradrenaline $(N)$ and hydroxytyramine $(H)$; (2) urine extract. (b) Fluorescence after spraying with ethylenediamine.
For qualitative study the chromatograms were sprayed with a mixture of ethylenediamine, two parts, and $10 \%(\mathrm{w} / \mathrm{v})$ ammonia, eight parts. Catecholamines appeared as green or yellow fluorescent spots or bands in ultra-violet light. The colour of the fluorescence varied with the concentration of the spot, becoming more yellow with increasing concentration. Butanol chromatograms of urinary extracts usually showed an ultraviolet absorbing zone of low $\mathbf{R}_{F}$ (approximately $0.10-0.20$ ) well behind the position of noradrenaline. Another zone of ultra-violet absorption which was sometimes well defined, but at other times only visible as a faint cloud, corresponded to the positions of the catecholamines on the guide strip. After spraying two or three zones of green to yellow fluorescence appeared in identical positions. The chromatogram contained no other zones with this type of fluorescence ; in particular, the front parts of the chromatogram were free of fluorescent material, showing the absence of catechol acetic acid ( $R_{F}$ about 0.78$)$.

Fig. 2a shows contact prints of chromatograms photographed in ultra-violet light (Markham and 
Smith, 1951). The chromatograms are those of a urine extract with its accompanying guide strip, run with the butanol solvent. It is evident that the absorbing areas on the guide strip are matched by corresponding ones on the urine strip. These same strips were subsequently sprayed with ethylenediamine, and in Fig. $2 b$ an attempt has been made to photograph the resultant fluorescence. Two brightly fluorescent bands can be seen which correspond to the zones occupied by noradrenaline and hydroxytyramine. This particular extract happened to have a low adrenaline content, and the adrenaline band, which is situated between those of noradrenaline and hydroxytyramine, is therefore barely visible. It is, however, obvious that there are no other well-defined fluorescent areas outside those occupied by catecholamines.

Quantitative Paper Chromatography.-Urine extracts were concentrated and dissolved in acetone as described above. The acetone extract was divided into two parts : one was applied to a paper strip destined for analysis after irrigation; to the other were added 10-30 $\mu \mathrm{g}$. of adrenaline, noradrenaline, and hydroxytyramine, and the mixture was applied to a second paper strip which was sprayed with ethylenediamine after irrigation. The fluorescent zones were marked with pencil and transverse lines were drawn so as to effect optimal separation. The paper strip for analysis was cut across along superimposed lines. These sections and others cut from adjoining areas were extracted with $10 \mathrm{ml} .0 .01 \mathrm{~N}-\mathrm{HCl}$ overnight and the extracts were finally analysed by the two fluorimetric methods. Results are shown in Table II. The zones overlap considerably, yet there is an obvious tendency for the bulk of each amine to accumulate in the expected position. Recoveries varied between 45 and $75 \%$, though the recovery of adrenaline in experiment 2 was lower. In model experiments with pure solutions recoveries were about 50 to $60 \%$. On the whole, it seems justified to conclude that the paper chromatographic experiments support the specificity of the fluorimetric method described.

DOPA.-If DOPA occurred in urine it would accompany the catecholamines in the resin eluate. Particular attention was paid to this possibility in view of the observation of Medes (1932), which, however, has remained unique so far. On a chromatogram run with butanol solvent DOPA is situated behind noradrenaline $\left(R_{F}\right.$ of DOPA 0.23-0.25), while with the phenol solvent DOPA and noradrenaline migrate at the same rate. In the eluate from a paper chromatogram DOPA
TABLE II

QUANTITATIVE PAPER CHROMATOGRAPHY OF PURIFIED URINE EXTRACTS

\begin{tabular}{|c|c|c|c|c|c|c|}
\hline $\begin{array}{c}\text { Experi- } \\
\text { ment } \\
\text { No. }\end{array}$ & Solvent & $\begin{array}{l}\text { Paper } \\
\text { Sec- } \\
\text { tion } \\
\text { No. }\end{array}$ & $\underset{\text { (approx.) }}{\mathbf{R}_{\boldsymbol{F}}}$ & $\begin{array}{c}\text { Adren- } \\
\text { aline } \\
(\mu \mathrm{g} .)\end{array}$ & $\begin{array}{c}\text { Nor- } \\
\text { adren- } \\
\text { aline } \\
(\mu \mathrm{g} .)\end{array}$ & $\begin{array}{c}\text { Hyd- } \\
\text { roxytyr- } \\
\text { amine } \\
(\mu \mathrm{g} .)\end{array}$ \\
\hline \multirow[t]{2}{*}{1} & \multirow[t]{2}{*}{ Butanol } & $\begin{array}{l}1 \\
2 \\
3 \\
4 \\
5\end{array}$ & $\begin{array}{l}0 \cdot 113-0 \cdot 186 \\
0 \cdot 186-0.262 \\
0.262-0.305 \\
0.305-0 \cdot 390 \\
0.390-0.475\end{array}$ & $\begin{array}{l}0 \\
0.010 \\
0.015 \\
0.275 \\
0.015\end{array}$ & $\begin{array}{l}0 \\
0.265 \\
0.330 \\
0.030 \\
0.015\end{array}$ & $\begin{array}{l}0 \\
0 \\
0 \cdot 150 \\
0 \cdot 300 \\
1 \cdot 570\end{array}$ \\
\hline & & & $\begin{array}{l}\text { Total } \\
\text { Applied to } \\
\text { paper } \\
\text { Recovered } \\
(\%)\end{array}$ & $\begin{array}{l}0.315 \\
0.550 \\
57.5\end{array}$ & $\begin{array}{l}0.640 \\
1.03 \\
62\end{array}$ & $\begin{array}{l}2 \cdot 020 \\
3 \cdot 68 \\
55\end{array}$ \\
\hline \multirow[t]{2}{*}{2} & \multirow[t]{2}{*}{, } & $\begin{array}{l}1 \\
2 \\
3 \\
4 \\
5\end{array}$ & $\begin{array}{l}0.151-0.205 \\
0.205-0.256 \\
0.256-0.293 \\
0.293-0.355 \\
0.355-0.426\end{array}$ & $\begin{array}{l}0 \\
0 \cdot 025 \\
0 \cdot 145 \\
0 \cdot 015 \\
0\end{array}$ & $\begin{array}{l}0 \\
0 \cdot 630 \\
0 \cdot 100 \\
0 \\
0\end{array}$ & $\begin{array}{l}0 \\
0 \\
0 \\
1.080 \\
0 \cdot 595\end{array}$ \\
\hline & & & $\begin{array}{l}\text { Total } \\
\text { Applied to } \\
\text { paper } \\
\text { Recovered } \\
(\%)\end{array}$ & $\begin{array}{l}0.185 \\
0.750 \\
24.5\end{array}$ & $\begin{array}{l}0.730 \\
1.60 \\
45 \cdot 6\end{array}$ & $\begin{array}{c}1.675 \\
3.08 \\
54.4\end{array}$ \\
\hline \multirow[t]{2}{*}{3} & \multirow[t]{2}{*}{ Phenol } & $\begin{array}{l}1 \\
2 \\
3 \\
4 \\
5\end{array}$ & $\begin{array}{l}0 \cdot 115-0 \cdot 230 \\
0 \cdot 230-0 \cdot 380 \\
0 \cdot 380-0.470 \\
0.470-0.640 \\
0.640-0.760\end{array}$ & $\begin{array}{l}0 \\
0.020 \\
0.020 \\
0.275 \\
0.090\end{array}$ & $\begin{array}{l}0 \\
1.02 \\
0.13 \\
0.045 \\
0\end{array}$ & $\begin{array}{l}0 \\
0 \cdot 39 \\
0 \cdot 165 \\
4 \cdot 15 \\
0.40\end{array}$ \\
\hline & & & $\begin{array}{l}\text { Total } \\
\text { Applied to } \\
\text { paper } \\
\text { Recovered } \\
(\%)\end{array}$ & $\begin{array}{l}0.405 \\
0.90 \\
45\end{array}$ & $\begin{array}{l}1 \cdot 195 \\
1.60 \\
75\end{array}$ & $\begin{array}{c}5 \cdot 105 \\
7 \cdot 10 \\
72 \cdot 5\end{array}$ \\
\hline
\end{tabular}

In chromatograms run with butanol-acetic acid solvent section No. 2 corresponded with the noradrenaline spot on the guide strip section No. 3 with the adrenaline spot, and section No. 4 with the hydroxytyramine spot. In the chromatogram run with pheno solvent section No. 2 corresponded with the noradrenaline spot section No. 3 with the hydroxytyramine spot, and section No. 4 with the adrenaline spot.

would give the following reactions: a positive ninhydrin reaction; fluorescence in the reaction of Euler and Floding (1955a); fluorescence after condensation with ethylenediamine, characterized by its low solubility in isobutanol. Using these criteria we could find no evidence for the presence of DOPA in urine. In addition the following test was carried out: a urine extract was chromatographed on paper with the butanol solvent and the resulting chromatogram was cut lengthwise along the midline. One half was sprayed with the ethylenediamine reagent, the other with ninhydrin. A purple ninhydrin spot appeared, having an $R_{p}$ of about 0.20 , just in front of an ultra-violet-absorbing area. The area where DOPA would have been expected gave no reaction to either spray. Ethylenediamine fluorescence was found between $R_{F} 0.27$ and 0.43 , approximately, showing the presence of catecholamines. On the guide strip which contained $5 \mu \mathrm{g}$. DOPA a zone between $R_{F} 0.24$ and 0.27 gave both ethylenediamine and ninhydrin reactions. 
Bioassays.-Bioassays were carried out on concentrated purified extracts of urine with the methods described by Gaddum (1950), in which the inhibition of carbachol-induced contractions is measured in the isolated rat's uterus and ascending colon. While the uterus preparation is much more sensitive to adrenaline than to noradrenaline, the colon preparation responds about equally to both amines. The response of both preparations to hydroxytyramine may be neglected (cf. Gaddum, Peart, and Vogt, 1949).

In Fig. 3 the results obtained with the colon method are plotted against the results of the chemical method. Although the scatter is appreciable, there is a significant regression $(P=0.02)$ and the observed and theoretical regression lines are very close.

Results obtained with the uterus method, on the other hand, were disappointing. Good agreement with the chemical assay was found in two cases, but in the others bioassay indicated only 5 to $50 \%$ of the amount expected from the chemical analysis. This may have been due partly to racemization, partly to interference, since it was shown on several occasions that the addition of known amounts of adrenaline to urine extracts had only 20 to $40 \%$ of the theoretical effect.

\section{Recovery}

For recovery experiments a mixture of adrenaline, noradrenaline, and hydroxytyramine was added to one of two identical samples of hydro-

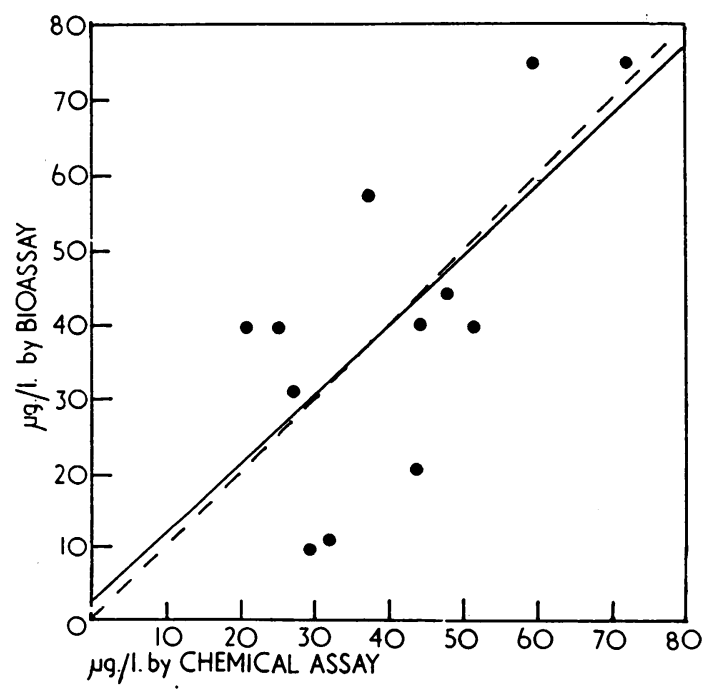

FIG. 3.-Estimation of adrenaline + noradrenaline in urinary extracts ; bioassay versus chemical assay. Full line: observed regression $(y=2.84+0.927 x$; standard error of regression coefficient $\mathrm{sb}=$ 0.328). Dashed line: theoretical regression.
TABLE III

RECOVERY EXPERIMENTS

\begin{tabular}{|c|c|c|c|c|c|c|}
\hline \multirow{2}{*}{$\begin{array}{c}\text { Sample } \\
\text { No. }\end{array}$} & \multirow{2}{*}{ Amine* } & \multirow{2}{*}{$\begin{array}{c}\text { Pre- } \\
\text { formed } \\
(\mu \mathrm{g} \cdot / \\
60 \mathrm{mi} .)\end{array}$} & \multirow{2}{*}{$\begin{array}{c}\text { Added } \\
(\mu \mathrm{g} . / \\
60 \mathrm{ml} .)\end{array}$} & \multirow{2}{*}{$\begin{array}{c}\text { Found } \\
\text { After } \\
\text { Addition } \\
(\mu \mathrm{g} . ! \\
60 \mathrm{ml} .)\end{array}$} & \multicolumn{2}{|c|}{ Recovery } \\
\hline & & & & & $\mu \mathrm{g}$ & $\%$ \\
\hline 1 & $\begin{array}{l}\mathbf{A} \\
\mathbf{N} \\
\mathbf{H}\end{array}$ & $\begin{array}{l}0.47 \\
1.40 \\
3.90\end{array}$ & $\begin{array}{l}2 \cdot 00 \\
3 \cdot 70 \\
4 \cdot 00\end{array}$ & $\begin{array}{l}1 \cdot 80 \\
4 \cdot 20 \\
7 \cdot 30\end{array}$ & $\begin{array}{l}1 \cdot 33 \\
2 \cdot 80 \\
3 \cdot 40\end{array}$ & $\begin{array}{l}65 \\
76 \\
85\end{array}$ \\
\hline 2 & $\begin{array}{l}\mathbf{A} \\
\mathbf{N} \\
\mathbf{H}\end{array}$ & $\begin{array}{l}0.81 \\
2.00 \\
5 \cdot 45\end{array}$ & $\begin{array}{l}2 \cdot 00 \\
3 \cdot 70 \\
4 \cdot 00\end{array}$ & $\begin{array}{l}2 \cdot 48 \\
5 \cdot 20 \\
9 \cdot 85\end{array}$ & $\begin{array}{l}1 \cdot 67 \\
3 \cdot 20 \\
4 \cdot 40\end{array}$ & $\begin{array}{c}83 \cdot 5 \\
86 \cdot 5 \\
110\end{array}$ \\
\hline 3 & $\begin{array}{l}\mathbf{A} \\
\mathbf{N} \\
\mathbf{H}\end{array}$ & $\begin{array}{l}0.44 \\
1 \cdot 22 \\
4.41\end{array}$ & $\begin{array}{l}1.85 \\
4.00 \\
3.70\end{array}$ & $\begin{array}{l}1 \cdot 74 \\
4 \cdot 36 \\
7 \cdot 01\end{array}$ & $\begin{array}{l}1 \cdot 30 \\
3 \cdot 14 \\
2 \cdot 60\end{array}$ & $\begin{array}{l}70 \cdot 5 \\
78 \cdot 5 \\
70 \cdot 4\end{array}$ \\
\hline 4 & $\begin{array}{l}\mathbf{A} \\
\mathbf{N} \\
\mathbf{H}\end{array}$ & $\begin{array}{l}0.91 \\
0.94 \\
2 \cdot 10\end{array}$ & $\begin{array}{l}1 \cdot 80 \\
3.90 \\
400\end{array}$ & $\begin{array}{l}2 \cdot 34 \\
4 \cdot 25 \\
5 \cdot 50\end{array}$ & $\begin{array}{l}1.43 \\
3.31 \\
3.40\end{array}$ & $\begin{array}{l}79 \cdot 5 \\
85 \\
85\end{array}$ \\
\hline 5 & $\begin{array}{l}\mathbf{A} \\
\mathbf{N} \\
\mathbf{H}\end{array}$ & $\begin{array}{l}0 \cdot 87 \\
1 \cdot 13 \\
4 \cdot 13\end{array}$ & $\begin{array}{l}2 \cdot 00 \\
4 \cdot 00 \\
4 \cdot 20\end{array}$ & $\begin{array}{l}2 \cdot 62 \\
4 \cdot 52 \\
8 \cdot 05\end{array}$ & $\begin{array}{l}1 \cdot 75 \\
3 \cdot 39 \\
3 \cdot 92\end{array}$ & $\begin{array}{l}88 \\
85 \\
93\end{array}$ \\
\hline 6 & $\begin{array}{l}\mathbf{A} \\
\mathbf{N} \\
\mathbf{H}\end{array}$ & $\begin{array}{l}1 \cdot 11 \\
1 \cdot 56 \\
5 \cdot 00\end{array}$ & $\begin{array}{l}2 \cdot 00 \\
4 \cdot 00 \\
4 \cdot 20\end{array}$ & $\begin{array}{l}2 \cdot 70 \\
5 \cdot 20 \\
7 \cdot 98\end{array}$ & $\begin{array}{l}1 \cdot 59 \\
3.64 \\
2.98\end{array}$ & $\begin{array}{l}80 \\
91 \\
71\end{array}$ \\
\hline 7 & $\begin{array}{l}\mathbf{A} \\
\mathbf{H}\end{array}$ & $\begin{array}{l}0.73 \\
1.82 \\
9.15\end{array}$ & $\begin{array}{l}2.00 \\
3.40 \\
6 \cdot 00\end{array}$ & $\begin{array}{r}2 \cdot 62 \\
4 \cdot 90 \\
15 \cdot 30\end{array}$ & $\begin{array}{l}1 \cdot 89 \\
3.08 \\
6 \cdot 15\end{array}$ & $\begin{array}{c}95 \\
906 \\
102\end{array}$ \\
\hline 8 & $\begin{array}{l}\mathbf{A} \\
\mathbf{N} \\
\mathbf{H}\end{array}$ & $\begin{array}{r}0.83 \\
1.69 \\
13.90\end{array}$ & $\begin{array}{l}2.00 \\
3.40 \\
6 \cdot 00\end{array}$ & $\begin{array}{r}2 \cdot 68 \\
4.48 \\
18.90\end{array}$ & $\begin{array}{l}1 \cdot 85 \\
2 \cdot 79 \\
5 \cdot 00\end{array}$ & $\begin{array}{l}92 \cdot 5 \\
82 \cdot 5 \\
83 \cdot 5\end{array}$ \\
\hline 9 & $\begin{array}{l}\mathbf{A} \\
\mathbf{H}\end{array}$ & $\begin{array}{r}1 \cdot 13 \\
2.89 \\
10 \cdot 80\end{array}$ & $\begin{array}{l}2 \cdot 10 \\
4 \cdot 20 \\
3 \cdot 25\end{array}$ & $\begin{array}{r}3.00 \\
6.95 \\
13.80\end{array}$ & $\begin{array}{l}1 \cdot 87 \\
4.06 \\
3 \cdot 00\end{array}$ & $\begin{array}{l}89 \\
97 \\
92 \cdot 5\end{array}$ \\
\hline 10 & $\begin{array}{l}\mathbf{A} \\
\mathbf{N} \\
\mathbf{H}\end{array}$ & $\begin{array}{r}1 \cdot 13 \\
2 \cdot 52 \\
10 \cdot 50\end{array}$ & $\begin{array}{l}2 \cdot 10 \\
4 \cdot 20 \\
3 \cdot 25\end{array}$ & $\begin{array}{r}3 \cdot 00 \\
6 \cdot 60 \\
14 \cdot 00\end{array}$ & $\begin{array}{l}1.87 \\
4.08 \\
3.50\end{array}$ & $\begin{array}{r}89 \\
97 \\
108\end{array}$ \\
\hline 11 & $\begin{array}{l}\mathbf{A} \\
\mathbf{N} \\
\mathbf{H}\end{array}$ & $\begin{array}{r}1.06 \\
2.60 \\
19 \cdot 50\end{array}$ & $\begin{array}{l}2.02 \\
4.05 \\
3.09\end{array}$ & $\begin{array}{r}2.60 \\
6 \cdot 55 \\
22 \cdot 50\end{array}$ & $\begin{array}{l}1.54 \\
3.95 \\
3.00\end{array}$ & $\begin{array}{l}76 \cdot 4 \\
97 \cdot 5 \\
97 \cdot 2\end{array}$ \\
\hline . & $\begin{array}{l}\mathbf{A} \\
\mathbf{N} \\
\mathbf{H}\end{array}$ & $\{$ mean & 土S.E. & $?$ & & $\begin{array}{l}826=2.82 \\
87.9 \pm 2.24 \\
90.7=4.01\end{array}$ \\
\hline
\end{tabular}

* $\mathrm{A}=$ Adrenaline. $\mathrm{N}=$ Noradrenaline. $\mathrm{H}=$ Hydroxytyramine.

lysed urine (usually $60 \mathrm{ml}$.). The amounts added were determined by analysis of the mixture. Results are shown in Table III. Mean recoveries of 11 experiments were 83,88 , and $91 \%$ for adrenaline, noradrenaline, and hydroxytyramine respectively.

\section{The Concentration of Catecholamines in Urine}

Table IV shows three groups of results. The first group consists of urine specimens collected from males, usually in the morning. These results are expressed in $\mu \mathrm{g}$./litre. The second group contains samples from patients with hypertension where the possibility of phaeochromocytoma had been envisaged. Since these samples were taken from the pooled 24-hour urine, they are not strictly comparable with the samples 
TABLE IV

CATECHOLAMINES IN URINE (MEANS \pm S.E.)

\begin{tabular}{|c|c|c|c|c|c|}
\hline Group & $\begin{array}{l}\text { No. of } \\
\text { Speci- } \\
\text { mens }\end{array}$ & $\begin{array}{c}\text { 24-hr. } \\
\text { Volume } \\
\text { (ml.) }\end{array}$ & $\begin{array}{l}\text { Adrenaline } \\
(\mu \mathrm{g} .1 .)\end{array}$ & $\begin{array}{c}\text { Noradren- } \\
\text { aline } \\
(\mu \mathrm{g} \cdot 1 \mathrm{l})\end{array}$ & $\begin{array}{c}\text { Hydroxy- } \\
\text { tyramine } \\
(\mu \mathrm{g} \cdot / 1 .)\end{array}$ \\
\hline $\begin{array}{l}\text { Personnel } \\
\text { Patients } \\
\text { with } \\
\text { hyper- } \\
\text { tension } \\
\text { Patient }\end{array}$ & $\begin{array}{l}32 \\
11\end{array}$ & $\begin{array}{c}1,396 \\
\text { (mean) }\end{array}$ & $\begin{array}{r}11 \cdot 24 \pm 0 \cdot 81 \\
24 \cdot 3 \pm 3 \cdot 60\end{array}$ & $\begin{array}{c}25.41 \pm 1.81 \\
\mu \mathrm{g} . / 24 \mathrm{hr} . \\
46.4 \pm 6.83 \\
\mu \mathrm{g} . / 24 \mathrm{hr} . \\
\text { ngle estimatio }\end{array}$ & $\begin{array}{l}76 \cdot 93 \pm 9 \cdot 21 \\
249 \cdot 9 \pm 52 \cdot 9 \\
\text { ns) }\end{array}$ \\
\hline $\begin{array}{l}\text { with } \\
\text { phaeo- } \\
\text { chromo- } \\
\text { cytoma }\end{array}$ & $\begin{array}{l}1 \text { (a) } \\
1 \text { (b)* }\end{array}$ & $\begin{array}{l}2,950 \\
2,440\end{array}$ & $\begin{array}{l}36 \cdot 9 \\
48 \cdot 2\end{array}$ & $\begin{array}{l}257 \\
322\end{array}$ & $\begin{array}{l}3,420 \\
1,430\end{array}$ \\
\hline
\end{tabular}

* After two days on protein-free diet.

of the first group. If, in spite of this, the concentrations (in $\mu \mathrm{g}$./1.) are compared in the two groups, it is found that the concentrations of adrenaline and hydroxytyramine are significantly higher in the hypertensive group $(\mathrm{P}<0.01)$ and that the increase of noradrenaline concentration is probably significant $(P=0.035)$. Since the excretion rate of catecholamines is highest during the morning hours (Euler, Hellner-Björkman, and Orwén, 1955), the difference might have been accentuated if the 24-hour samples had been compared, although, of course, urine flow is also accelerated during the morning hours.

The excretion rate of adrenaline and noradrenaline found in the first group agrees well with the figures published by Euler and Hellner (1951), though in more recent work Euler and his co-workers (Euler, Franksson, and Hellström, 1954 ; Euler et al., 1955) give higher figures for noradrenaline excretion and lower figures for adrenaline excretion.

There is a much greater variation in hydroxytyramine concentration from sample to sample than in that of adrenaline or noradrenaline. The coefficient of variation (100 S.D./mean), which is about 40 for adrenaline and noradrenaline in the two groups, is about 70 for hydroxytyramine.

Finally a patient was investigated from whom a phaeochromocytoma was subsequently removed. Here the excretion of all three catecholamines was increased, and it is interesting to note that by far the highest increase was found in hydroxytyramine excretion. The examination was repeated after the patient had been on a protein-free diet for two days. This did not affect the excretion of adrenaline and noradrenaline, but it reduced the excretion of hydroxytyramine by more than half. This result, in conjunction with the variability of hydroxytyramine excretion noted above, is in accord with the conception of hydroxytyramine as a precursor of noradrenaline and adrenaline. If it is produced in excess of requirements, its excretion may be expected to rise. The vastly increased excretion in the case of phaeochromocytoma is presumably the consequence of an excessive formation in the tumour cells. It suggests that normally the principal site of hydroxytyramine synthesis is the adrenal medulla.

\section{A Note on the Occurrence and Estimation of Catecholamines in Plasma}

When the catechol compounds of acid-hydrolysed urine are absorbed on aluminium oxide and samples of the eluate therefrom analysed, without further purification, by the fluorimetric method of Weil-Malherbe and Bone (1953) and by that of Lund (1950), it is found that the former gives much higher results than the latter. When a similar experiment is carried out on an eluate from plasma, both methods yield results which are in reasonable agreement (Weil-Malherbe and Bone, 1954b ; Weil-Malherbe, 1955). This has recently been confirmed in an extensive new series of experiments in which the ethylenediamine method has been compared with the method of Euler and Floding (1955a). It has also been shown that, when alumina eluates from plasma were further purified by passage through "zeokarb," the results were practically identical with those obtained before the resin treatment. It is concluded that, unlike urine, plasma does not contain neutral catechols, acidic catechols, or hydroxytyramine in measurable quantities; nor was there any evidence for the occurrence of DOPA. The method of Weil-Malherbe and Bone (1952, 1953) is therefore valid for plasma. A full account of these results will be presented elsewhere.

\section{Summary}

A chemical method is described for the estimation of adrenaline, noradrenaline, and hydroxytyramine in urine consisting of the following steps :

(a) The catechol fraction is isolated by adsorption on alumina.

(b) The basic catechol fraction is isolated by adsorption on cation exchange resin.

(c) The sum of the three catecholamines is esti- $\frac{\stackrel{O}{\mathbb{D}}}{\mathscr{D}}$ mated fluorimetrically by the method of Weil- @? Malherbe and Bone (1952). Adrenaline and nor- 7 adrenaline are estimated separately by the fluorimetric method of Euler and Floding (1955a). Hydroxytyramine is obtained by difference.

The specificity of the procedure was investigated by paper chromatography and bioassay. Paper 8 
chromatography showed the presence of the three catecholamines in urinary extracts and the absence of substances capable of producing interfering fluorescence. No evidence was found for the presence of 3:4-dihydroxyphenylalanine in urine.

Bioassays with the rat's ascending colon correlated reasonably well with the chemical assays. Those with the rat's uterus were less satisfactory, presumably owing to interference.

Mean recoveries of added catecholamines were 83,88 , and $91 \%$ for adrenaline, noradrenaline, and hydroxytyramine respectively.

The method has been applied to a group of normal subjects, a group of hypertensive cases, and a patient with phaeochromocytoma. Hydroxytyramine excretion was more variable from sample to sample than that of adrenaline and noradrenaline in both the normal and hypertensive groups. The excretion of hydroxytyramine in a case of phaeochromocytoma showed a greater relative increase than that of adrenaline or noradrenaline.

\section{Addendum}

With a new batch of "zeokarb" 225 hydroxytyramine was not always quantitatively eluted under the conditions described. It was found that the size of the column could be safely reduced if a finer grade resin was used. With 100-200 mesh “zeokarb" 225 , columns containing $0.5 \mathrm{~g}$. damp resin gave good results; they were washed with $50 \mathrm{ml}$. $0.2 \mathrm{~N}$ acetic acid and eluted with $25 \mathrm{ml}$. $0.2 \mathrm{~N} \mathrm{BaCl}_{2}$.

Columns containing $0.5 \mathrm{~g}$. of 100-200 mesh " amberlite" IRC-50 (damp), buffered at pH 6.5, may be used instead of "zeokarb" columns. Eluates from alumina are mixed with 0.1 vol. $1 \%$ E.D.T.A. (disodium salt) to prevent precipitation of traces of aluminium hydroxide and adjusted to $p \mathrm{H} \mathrm{6.5.} \mathrm{The}$ columns are washed with $60 \mathrm{ml}$. water and eluted with $10 \mathrm{ml}$. N-HCl. Recoveries were between 90 and $100 \%$ for all three catecholamines.

The authors wish to express their gratitude to $\mathrm{Mr}$. A. C. Drysdale for assistance with bioassays, to Mr. R. A. Parkins, D.F.H., for the design and construction of the photomultiplier circuit and power pack, and to the Medical Research Council for a grant for technical assistance.

\section{REFERENCES}

Abbott, L. D., Jr., and Smith, J. D. (1949). J. biol. Chem., 179, 365. Abelin, I., and Goldstein, M. (1955). Biochem. Z., 327, 72.

Aronow, L., and Howard, F. A. (1955). Fed. Proc., 14, 315.

Aronow, L., and Howard, F. A. (1955). Fed. Proc., 14, 315. $22,87$. Bone, A. D. (1953). J. med. Lab. Technol., 11, 212.

Clark, W. G., Akawie, R. I., Pogrund, R. S., and Geissman, T. A. (1950). 18th Internat. Physiol. Congress Abstracts of Communications, p. 159. Copenhagen.

Elmadjian, F., Lamson, E., and Neri, R. (1955). Fed. Proc., 14, 44

Engel, A., and Euler, U. S. von (1950). Lancet, 2, 387.

Erne, K., and Canbäck, T. (1955). J. Pharm. Pharmacol., 7, 248.

Euler, U. S. von (1951). Ann. Surg., 134, 929.

- Euler, C. von, and Floding, I. (1955). Acta physiol. scand., 33, Suppl. 118, p. 32.

and Floding, I. (1955a). Ibid., 33, Suppl. 118, p. 45. - (1955b). Ibid., 33, Suppl. 118, p. 57.

Franksson, C., and Hellström, J. (1954). Ibid., 31, 1. Hamberg, U., and Hellner, S. (1951). Biochem. J., 49, 655. and Hellner, S. (1951). Acta physiol. scand., 22, 161.

Hellner-Björkman, S., and Orwén, I. (1955). Ibid., 33, Suppl. 118, p. 10.

- and Orwén, I. (1955). Ibid., 33, Suppl. 118, p. 1.

Fiker, S. (1953). Procovni lék., 5, 206. Quoted from Chem. Abstr., 49, 3734g (1955).

Gaddum, J. H. (1950). Meth. med. Res., 3, 116.

Peart, W.S., and Vogt, M. (1949). J. Physiol. (Lond.), 108, 467. Holtz, P., Credner, K., and Koepp, W. (1942). Arch. exp. Path. Pharmak., 200, 356.

Hoobler, S. W., Agrest, A., and Warzynski, R. J. (1954). J. clin. Invest., 33, 943.

Kawamoto, K. (1954). Symposia on Enzyme Chem. (Japan), 9, 52. Quoted from Chem. Abstr., 48, 7727b (1954).

Lund, A. (1950). Acta pharmacol., 6, 137.

Mann, M. (1953). J. Pharm. Pharmacol., 5, 1024.

Markham, R., and Smith, J. D. (1951). Biochem. J., 49, 407.

Medes, G. (1932). Ibid., 26, 917.

Moore, S., and Stein, W. H. (1951). J. biol. Chem., 192, 663.

Pekkarinen, A., and Pitkänen, M.-E. (1955). Scand. J. clin. Lab. Invest., 7, 1.

Weil-Malherbe, H. (1955). J. ment. Sci., 101, 733. and Bone, A. D. (1952). Biochem. J., 51, 311. (1953). Lancet, 1, 974. 